\title{
U.S. Growers' Willingness to Pay for Improvement in Rosaceous Fruit Traits
}

\author{
Chengyan Yue, Shuoli Zhao, Karina Gallardo, \\ Vicki McCracken, James Luby, and Jim McFerson
}

\begin{abstract}
As growers adopt and diffuse improved food crop cultivars, their investment decisions for producing new cultivars control product accessibility and directly affect the entire supply chain. In this study, we estimated growers' willingness to invest (willingness to pay (WTP)) in cultivars with improved quality traits for five rosaceous fruit crops: apple, peach, strawberry, sweet cherry, and tart cherry. WTP values differed by crop, but fruit flavor was consistently rated one of the most important traits, with higher WTP. This information will help breeding programs focus resources to develop superior cultivars for long-term economic sustainability of the rosaceous fruit industry.
\end{abstract}

Key words: rosaceous fruits, willingness to pay, choice experiments, quality attributes

\section{Introduction}

The plant family Rosaceae comprises 90 genera and over 3000 species, many with significant economic importance throughout the United States, including almond, apple, blackberry, cherry, peach, pear, plum, raspberry, rose, and strawberry (Iezzoni 2010). Rosaceous fruits and nuts are consumed as fresh and processed products that contribute to human well-being by providing essential nutrients such as vitamins, minerals, dietary fiber, and components

Chengyan Yue is an associate professor at the Departments of Applied Economics and Horticultural Science, Bachman Endowed Chair in Horticultural Marketing, University of Minnesota-Twin Cities; Shuoli Zhao is a Ph.D. student at the Department of Applied Economics, University of Minnesota-Twin Cities; Karina Gallardo is an associate professor at the School of Economics, Washington State University; Vicki McCracken is professor at the School of Economics, Washington State University; James Luby is a professor at the Department of Horticultural Science, University of Minnesota-Twin Cities; Jim McFerson is Director of the Washington Tree Fruit Research Commission. Correspondence: Chengyan Yue - 1970 Folwell Avenue • St. Paul, MN 55108 • Phone 612.626.3974•Email yuechy@umn.edu.

This research was funded by the USDA National Institute of Food and Agriculture Specialty Crop Research Initiative projects "RosBREED: Enabling marker-assisted breeding in Rosaceae" (200951181-05808) and "RosBREED: Combining Disease Resistance with Horticultural Quality" (2014-51181-22378).

Agricultural and Resource Economics Review 46/1 (April 2017) 103-122

(C) The Author(s) 2017. This is an Open Access article, distributed under the terms of the Creative

Commons Attribution licence (http://creativecommons.org/licenses/by/4.0/), which permits unrestricted re-use, distribution, and reproduction in any medium, provided the original work is 
that help reduce the risk of cancer, heart disease, and other chronic diseases (Ding and Lu 2004). Rosaceous crops are produced throughout the United States, so enhancing the economic sustainability of these industries benefits producers and their communities, the entire supply chain, and society in general.

Developing and deploying superior new cultivars that meet consumer, supply chain, and producer demands is an obvious, if complicated, approach to benefit all parties. Rosaceous crop breeding programs have successfully met these dynamic demands and developed cultivars that are more desirable, available, affordable, and healthier for consumers while at the same time benefitting other stakeholders in the supply chain (Iezzoni 2010, Gallardo et al. 2012). In general, plant-breeding programs require significant investments of financial, human, and time resources. Constraints in these resources require plant breeders to set priorities in order to focus on a limited set of traits, with the goal of developing a new, breakthrough cultivar. Breeding rosaceous crops is particularly constrained by the relatively higher need for technical and land resources compared to agronomic crops; establishment of priority traits and their desirable levels of expression is critical. Although rosaceous crop breeders develop an effective sense about the relative importance of traits from their interactions with consumers, growers, and other supply chain parties, the marginal values of these traits are unknown (Gallardo et al. 2012). For example, a common perception among peach breeders is that external fruit color is important when selecting for peach cultivars; however, the marginal value for improving external color from not desirable (lack of skin blush/color) to desirable (cream/yellow background color with a red blush) is unknown. Knowledge of the relative values of fruit traits to different stakeholders can contribute to enhancing the efficiency of breeding programs by enabling breeders to focus on improving the traits of greatest value to the market (Yue et al. 2012).

Because growers make the decision to plant new cultivars, absorbing the risk of adopting and diffusing the innovative products, they represent the immediate clientele in the supply chain for breeding programs. Their risk includes up-front investment costs to establish an orchard and potentially, a long payback or even a loss on the investment (Gallardo et al. 2012, Yue et al. 2013). Thus, growers have customarily provided considerable input to breeding programs, seeking cultivars most suited to their specific environmental and market conditions.

Despite this, most studies in the applied economics literature have focused on consumer and market intermediary preferences. Limited research has been conducted to elicit grower preferences and growers' willingness to invest (hereafter referred to as WTP (willingness-to-pay)) to improve traits in the rosaceous crops they produce. For example, in previous studies of consumers, the most important apple fruit quality traits were crispness, sweetness, firmness, flavor, and taste (Manalo 1990, Kajikawa 1998, Jesionkowska et al. 2006, McCluskey et al. 2013). Size, taste or flavor, freshness, sweetness, firmness, color, and soluble solids concentration (SSC) have been identified as important sweet cherry traits (Dever et al. 1996, 
Kappel et al. 1996, Crisosto et al. 2003). Freedom from defects, color, size, SSC, flavor, and sweetness are positively correlated with fresh peach retail prices and overall acceptability for peaches (Jordan et al. 1986, Parker et al. 1991, Ravaglia et al. 1996, Predieri et al. 2006). Similarly, for strawberries, flavor, sweetness, SSC, firmness, color, and size were most important (Ford et al. 1996, Colquhoun et al. 2012, Lado et al. 2010, Safley et al. 1999).

Other studies have focused on market intermediaries. For apple, U.S. market intermediaries were willing to pay premiums for improved fruit shelf life, external appearance, firmness, flavor, and crispness. Sweet cherry market intermediaries were willing to pay price premiums for improvements in SSC, flavor, external color, size, and firmness. Peach market intermediaries in California had higher WTP for improved fruit SSC and firmness; peach market intermediary operations outside California had higher WTP for improved fruit size, firmness, SSC, and external color. U.S. strawberry market intermediaries had higher WTP for improved fruit flavor, firmness, and size (Gallardo et al. 2015). Park and Florkowski (2003) found taste to be important for peach growers' acceptance of a new cultivar.

As the upstream stakeholders in the supply chain, growers' preferences and WTP for growing cultivars with improved attributes depends on many factors. Production factors such as marketable yield levels, production costs, and ease of harvest can all affect WTP. Additionally, growers' demand for cultivars with improved attributes depends on the downstream stakeholders' (e.g., market intermediaries', retailers', and consumers') demands for such cultivars. Because of the many influential factors, such derived demand might not perfectly match the primary demand from consumers. For example, a tart cherry grower might greatly value fruit firmness to withstand damage from machine harvesting. However, firmness might not matter to tart cherry consumers as they mainly consume processed products such as juice or dried fruit. Different positions along the supply chain thus have different WTP. Growers' WTP measures the production cost they are willing to bear, and consumers' WTP corresponds to retail price. Even though growers and consumers are likely to exhibit different preferences for fruit attributes, we expect growers to assign higher values to attributes such as flavor, that enhance profits by increasing sales, making fruits more appealing to consumers.

Different from previous studies, this study elicits and evaluates grower WTP for fruit traits of important rosaceous crops. This study recruited randomly selected representative samples of growers from the top five producing states across the United States for fresh apple, peach, sweet cherry, strawberry, and processed tart cherry, accounting for more than $90 \%$ of the total national production for each crop. It is one of the socioeconomic studies by investigators in the RosBREED project, funded by the USDA National Institute for Food and Agriculture Specialty Crop Research Initiative. The goal of the project is to enable the use of DNA marker-assisted breeding in rosaceous crops and improve the efficiency of plant breeding programs. Correctly identifying the most important traits for marker development and 
deployment will optimize the human and financial resources required for this approach. This study directly addresses that need from a grower perspective.

\section{Data Collection and Survey Design}

The sample of U.S. apple, peach, strawberry, sweet cherry, and tart cherry producers was selected from a nationally comprehensive list held by Meister Media Inc., a trade magazine whose primary clientele are U.S. fruit growers. Survey questions were developed in consultation with scientists and industry experts. Survey data were collected from February to June 2012 using a combination of mail-in and internet survey methods.

To increase the response rate, we employed the total design method protocol (Dillman et al. 2009). The first contact with the potential respondents included a cover letter, a booklet questionnaire, postage-paid return envelope, and a $\$ 4$ pre-incentive. Over the a three-week period, reminders were sent via postcard, mail, and emails, along with updated and duplicate materials and information about completing the survey by mail or online with an individualized access code. In total, we sent out 2578 surveys, with 845 surveys completed (33\% response rate), including 321 apple growers, 124 peach growers, 86 strawberry growers, 215 sweet cherry growers and 99 tart cherry growers (Table 1).

Each survey had five sections. Section one, "About Your Farm," included multiple choice and rating questions regarding growers' main target market, importance of market factors such as transportation costs, and available selling channels. Section two, "Fruit and Plant Attributes," included Likertscale ratings of best-to-worst questions about growers' preferences for certain fruit and plant attributes and choice experiment scenario questions. Section three, "Adoption of New Varieties," included rating questions about the impact factors influencing new cultivar adoption. Section four, "Information about Your Farm Operation," asked about farm size, location, business structure, and gross income. Section five, "Information about You,"

\section{Table 1. Survey Response Rates}

\begin{tabular}{lcccc}
\hline Crop & $\begin{array}{l}\text { Sample } \\
\text { size }\end{array}$ & $\begin{array}{l}\text { Adjusted } \\
\text { sample size }\end{array}$ & $\begin{array}{l}\text { Total complete } \\
\text { surveys }\end{array}$ & $\begin{array}{l}\text { Response } \\
\text { rate (\%) }\end{array}$ \\
\hline Apple & 943 & 868 & 321 & 37.0 \\
Peach & 493 & 453 & 124 & 27.4 \\
Strawberry & 488 & 421 & 86 & 20.4 \\
Sweet cherry & 626 & 562 & 215 & 38.3 \\
Tart cherry & 331 & 274 & 99 & 36.1 \\
OVERALL & $\mathbf{2 8 8 1}$ & $\mathbf{2 5 7 8}$ & $\mathbf{8 4 5}$ & $\mathbf{3 3 . 2}$ \\
\hline
\end{tabular}


contained questions concerning survey participants' demographics: gender, age, years of experience, racial background, and formal education.

The analytical focus of this study are choice experiment questions in section two, designed to get estimates of grower preferences and WTP for fruit attributes. Choice experiments represent products in terms of a combination of attributes, allowing researchers to elicit values for various attributes simultaneously. Choice experiments can frame questions in a way such that they are similar to those faced by growers when choosing among cultivars to grow. Each participant was presented with a series of choice scenarios and asked to choose one alternative in each scenario. To lessen the cognitive burden on participants, only two alternatives (options A and B) were included in each scenario. If a participant did not want to choose either $A$ or $B$, they could choose option C (neither A nor B). Each of the two alternatives was characterized by a combination of different levels of fruit quality traits, along with cost. Because it was not practical to ask each participant to choose from all possible scenarios, a fractional factorial design was developed, to minimize scenario number and maximize profile variation. For further discussion of fractional factorial designs, see Louviere et al. (2000). The choice scenarios were generated using JMP ${ }^{\circledR} 8$ software (SAS Institute Inc., Cary, NC, USA).

Table 2 presents quality attributes and attribute levels for each crop included in the choice experiment. The attributes included are: apple (flavor, external appearance free from defects, crispness, firmness, size, and shelf life); peach (flavor, external appearance free from defects, firmness, size, and external color); strawberry (flavor, firmness, size, shelf life, external color, and internal color); sweet cherry (flavor, firmness, size, external color, sweetness, and shelf life); and tart cherry (external appearance free from defects, firmness, size, and external color). Additionally, we included total production, storage, and handling costs to test how sensitive growers were to the increased or decreased costs of producing cultivars with improved attributes. We decided to include these attributes, attribute levels, and cost levels based on feedback solicited from tree fruit production experts and grower advisory panel members. Each participant was provided information a grower would typically consider when deciding which cultivar(s) to grow. An example of a choice scenario for peach is shown in Table 3. Each participant was asked to complete eight choice scenarios. To make sure that these attributes were the most important attributes to growers, and that our attribute and cost levels reflected true-to-life situations in which growers decided which cultivars to grow, we pre-tested these choice scenarios with 5 to 10 growers in their respective industries before we distributed the surveys.

\section{Econometric Model}

Our empirical model builds on the random utility theory. We assume a grower derives utility when she sees her profits augmented. Growers' profits are a function of expected revenues derived from cultivars with improved fruit 
Table 2. Attributes and Attribute Levels for Rosaceous Crops

\begin{tabular}{|c|c|c|c|}
\hline Survey & Attributes & Level 1 & Level 2 \\
\hline Apple & $\begin{array}{l}\text { External appearance- Free of defects } \\
\text { Crispness } \\
\text { Firmness } \\
\text { Flavor } \\
\text { Size } \\
\text { Shelf life at retail }\end{array}$ & $\begin{array}{l}\text { More than } 3 \% \text { defects per lot } \\
\text { Not crisp } \\
\text { Less than } 14 \mathrm{lbs} \\
\text { Weak/mild flavor } \\
\text { Less than } 2.9 \text { inches }(100 \text { count }) \\
\text { Poor (Less than } 1 \text { week) }\end{array}$ & $\begin{array}{l}\text { Less than } 3 \% \text { defects per lot } \\
\text { Very crisp } \\
\text { More than } 14 \text { lbs } \\
\text { Full/intense flavor } \\
\text { More than } 2.9 \text { inches ( } 100 \text { count) } \\
\text { Good (More than } 1 \text { week) }\end{array}$ \\
\hline Peach & $\begin{array}{l}\text { External color } \\
\text { Size } \\
\text { External appearance- Free of defects } \\
\text { Firmness } \\
\text { Flavor } \\
\text { Sweetness (Soluble solids) }\end{array}$ & $\begin{array}{l}\text { Not desirable (lack of skin blush/ } \\
\quad \text { color) } \\
\text { Size } 80 \text { to size } 56^{*} \\
\text { Fair }(<70 \% \text { packout) } \\
\text { Less than } 10 \text { lbs } \\
\text { Weak/mild flavor } \\
\text { Low (Less than } 11^{\circ} \text { Brix) }\end{array}$ & $\begin{array}{l}\text { Desirable (cream/yellow background } \\
\quad \text { color with a red blush color) } \\
\text { Size } 50 \text { and larger* } \\
\text { Good (>85\% packout) } \\
\text { More than } 10 \text { lbs } \\
\text { Full/intense flavor } \\
\text { High (More than } 11^{\circ} \text { Brix) }\end{array}$ \\
\hline Strawberry & $\begin{array}{l}\text { Size } \\
\text { Internal color } \\
\text { External color } \\
\text { Firmness } \\
\text { Flavor } \\
\text { Shelf life }\end{array}$ & $\begin{array}{l}\text { Less than } 25 \mathrm{~g} / \text { fruit } \\
\text { Too light or too dark color } \\
\text { Too light or too dark color } \\
\text { Soft } \\
\text { Weak/mild flavor } \\
4 \text { days after harvest }\end{array}$ & $\begin{array}{l}\text { More than } 25 \mathrm{~g} / \text { fruit } \\
\text { Ideal red color } \\
\text { Ideal red color } \\
\text { Firm } \\
\text { Full/intense flavor } \\
9 \text { days after harvest }\end{array}$ \\
\hline $\begin{array}{l}\text { Sweet } \\
\text { Cherry }\end{array}$ & $\begin{array}{l}\text { External color } \\
\text { Size } \\
\text { Firmness } \\
\text { Sweetness (Soluble solids) } \\
\text { Flavor } \\
\text { Shelf life at retail }\end{array}$ & $\begin{array}{l}\text { Light red } \\
11 \text { row or smaller } \\
\text { Soft (less than } 300 \mathrm{~g} / \mathrm{mm} \text { ) } \\
\text { Low (Less than } 18{ }^{\circ} \text { Brix) } \\
\text { Weak/mild flavor } \\
\text { Less than } 1 \text { week }\end{array}$ & $\begin{array}{l}\text { Dark red } \\
10 \text { row or larger } \\
\text { Firm (more than } 300 \mathrm{~g} / \mathrm{mm} \text { ) } \\
\text { High (More than } 18^{\circ} \mathrm{Brix} \text { ) } \\
\text { Full/intense flavor } \\
\text { More than } 1 \text { week }\end{array}$ \\
\hline $\begin{array}{l}\text { Tart } \\
\text { Cherry }\end{array}$ & $\begin{array}{l}\text { External color } \\
\text { Size } \\
\text { External appearance- Free of defects } \\
\text { Firmness }\end{array}$ & $\begin{array}{l}\text { Poor red color } \\
\text { Nonuniform } \\
\text { More than } 4 \% \text { defects per lot } \\
\text { Soft }\end{array}$ & $\begin{array}{l}\text { Characteristic red color } \\
\text { Uniform } \\
\text { Less than } 4 \% \text { defects per lot } \\
\text { Firm }\end{array}$ \\
\hline
\end{tabular}

Weak/mild flavor

Less than 2.9 inches (100 count)

Less than 1 week

ot desirable (lack of skin blush/

Fair $(<70 \%$ packout $)$

10 lbs

Low (Less than $11^{\circ} \mathrm{Brix}$ )

Less than $25 \mathrm{~g} /$ fruit

ight or too dark

Soft

Soft (less than $300 \mathrm{~g} / \mathrm{mm}$ )

Soft

\footnotetext{
* For peach growers outsize of California, we used "2.25 inches diameter and up to 2.5 inches" and " 2.75 inches diameter and up to 3 inches" as the two levels
} 
Table 3. Choice Experiment Example (Peach)

\begin{tabular}{|c|c|c|c|}
\hline Attribute & Option A: & Option B: & Option C: \\
\hline External color & $\begin{array}{l}\text { Desirable (cream/yellow } \\
\text { background color with } \\
\text { a red blush color) }\end{array}$ & $\begin{array}{l}\text { Not desirable } \\
\text { (lack of skin } \\
\text { blush/color) }\end{array}$ & $\begin{array}{l}\text { Neither } \\
\text { Option }\end{array}$ \\
\hline Size & Size 50 and larger & Size 80 to size 56 & \\
\hline $\begin{array}{l}\text { External appearance free } \\
\text { of defects }\end{array}$ & Fair ( $<70 \%$ packout $)$ & $\begin{array}{l}\text { Good }(>85 \% \\
\text { packout })\end{array}$ & \\
\hline Firmness & More than $10 \mathrm{lbs}$ & Less than $10 \mathrm{lbs}$ & \\
\hline $\begin{array}{c}\text { Flavor (combination of } \\
\text { sweetness, sweet/tart } \\
\text { balance and aroma) }\end{array}$ & Full/intense flavor & $\begin{array}{l}\text { Weak/mild } \\
\text { flavor }\end{array}$ & \\
\hline Sweetness (soluble solids) & Low (Less than $11^{\circ}$ Brix) & $\begin{array}{l}\text { High (More than } \\
11^{\circ} \text { Brix) }\end{array}$ & \\
\hline $\begin{array}{l}\text { Total cost of production/ } \\
\text { storage/handling }\end{array}$ & $\$ 11 /$ box (25 lbs) & $\begin{array}{l}\$ 13.75 / \text { box }(25 \\
\quad \text { lbs })\end{array}$ & \\
\hline $\begin{array}{l}\text { Which option would you } \\
\text { choose? }\end{array}$ & & & \\
\hline
\end{tabular}

quality characteristics and expected costs resulting from planting a cultivar with a collection of attributes different from the status quo. We assume that cultivars with the improved plant and fruit quality attributes would exhibit different yield rates and fruit quality profiles compared to cultivars currently being grown. The WTP estimates in our study actually measure growers' willingness to invest in growing the improved cultivars. A grower would invest in a cultivar with improved attributes only when the benefit from developing improved attributes is higher than the corresponding cost. Taking flavor as example, the rationale for the WTP calculation is as follows: a grower is willing to invest in flavor improvement (or a cultivar with improved flavor) if the marginal increase in revenues brought by improvement in flavor is high enough to cover the marginal decrease in net revenue brought by the increase in the corresponding production cost. The theoretical framework of estimating grower WTP values was provided by Lusk and Hudson (2004) and Zapata and Carpio (2014), and the same derivation was also used by Gallardo et al. (2015).

Multinomial logit models and conditional logit models have been the standard techniques for discrete choice data analysis (Greene and Hensher 2010). However, the results of these models have limited applicability due to the restrictiveness of their independence of irrelevant alternatives (IIA) assumption. One alternative model, the mixed logit model, relaxes the IIA assumption by modeling preference heterogeneity and can be used to estimate random utility models (Train, 2009). The mixed logit model was 
used to study consumer preferences for cattle traits, animal welfare attributes, genetically modified foods and many other products (Ouma et al. 2007 Tonsor et al. 2009, Lusk et al. 2005)

For the methodology used in our study, a participant chooses an alternative variety representing a combination of fruit quality attributes from a set of choices, to maximize his/her profit. Suppose a choice set has $M$ alternatives $(i=1,2, \ldots, M)$. For participant $n(n=1,2, \ldots, N)$, the profit derived from the ith alternative can be represented as:

$$
\pi_{n i}=\beta_{n} X_{n i}+\varepsilon_{n i}
$$

$\pi_{n i}$ is individual $n$ 's profit from choosing alternative $i ; x_{n i}$ is a vector of observed variables representing the characteristics of alternative $i$ faced by individual $n$; $\beta_{n}$ is an unobserved random coefficient vector for each $n$ that varies in the population. Its density is $f(\beta \mid \theta)$, where vector $\theta$ contains the true parameters of this distribution; $\varepsilon_{i j}$ is an identical and independent distributed error term that follows extreme value distribution.

Among the $M$ alternatives, a grower participant would choose the alternative $i$, if and only if the alternative $i$ maximizes the grower's profit. Let $Y_{n}$ be a random variable whose value indicates the choice made by participant $n$. For a given $\beta_{n}$, the conditional probability of choosing alternative $i$ is:

$$
\mathcal{L}_{n i}(\beta)=\operatorname{Pr}\left(Y_{n}=i \mid \beta_{n}\right)=\operatorname{Pr}\left(\Pi_{n i}>\Pi_{n k} \mid \beta_{n}\right) \text { for all } k=1,2, \ldots, M ; k \neq i
$$

Because the error term follows an extreme value distribution, the conditional probability of choosing alternative $i$ is:

$$
\mathcal{L}_{n i}(\beta)=\operatorname{Pr}\left(Y_{n}=i \mid \beta_{n}\right)=\frac{e^{\beta_{n} X_{n i}}}{\sum_{k=1}^{M} e^{\beta_{n} X_{n k}}}
$$

Integrating (3) over the density of $\beta, f(\beta \mid \theta)$, we can obtain the unconditional choice probability in the mixed logit model:

$$
\operatorname{Pr}\left(Y_{n}=i\right)=\int \mathcal{L}_{n i}(\beta) f(\beta \mid \theta) d \beta
$$

The WTP value of an attribute's improvement from one level to another is the marginal rate of substitution between the attribute and the cost, and can be calculated by dividing the negative marginal utility of the attribute by the marginal utility of price. This calculation can be repeated to obtain the WTP for all included attributes. 


\section{Results and Discussion}

Summary statistics for the characteristics of survey participants and their operations are shown in Table 4. Most participants (across all 5 crops) were male $(>90 \%)$ and Caucasian $(>85 \%)$, with an average age of 58 years and about 25 years of experience. The average education level was a two-year college degree education. According to the reported farm size, tart cherry producers had comparatively the largest orchard size, with half managing over 50 acres. Most apple, peach, and sweet cherry orchards were between 5 and 49 acres, and nearly half of strawberry farms were less than 5 acres. Mean levels of reported gross income for apple, peach, and sweet cherry growers were similar. The average income level was between $\$ 50,000$ and $\$ 100,000$. Strawberry growers reported the lowest average income. However, only $15 \%$ of strawberry growers earned more than half of their total household income from strawberry production, indicating our sample mostly included operations with a relatively small strawberry component. In contrast, about $30 \%$ of apple and tart cherry growers obtained at least half of household income from their fruit-growing operations.

Based on the Likert-scale rating question responses, the following factors were rated the highest across all crops in terms of their influence on producers' decision to choose a new fruit cultivar: return on investment, consumer preference, suitability for climate/soil type, improvement in fruit quality, and potential market performance. Because each crop included a different set of attributes, and the grower respondents were different for each of the five crops, the mixed logit model was estimated separately by crop; see Table $5^{1}$. The attributes included were selected based on industry input and prior research identifying their importance. Hence it is not surprising that all estimated coefficients for attributes are statistically significant. The interactions were standardized, with mean of 0 and standard deviation of 1 . Furthermore, Table 6 reports calculated WTP point estimates and corresponding $95 \%$ confidence intervals for each crop.

Apple growers were willing to pay a premium of $\$ 0.43 / \mathrm{lb}$ for improving shelf life at retail from less than to greater than 1 week, consistent with industry assertions that maintaining quality characteristics as close as possible to harvest-time levels was crucial to repeated fresh market apple sales. In contrast, Gallardo et al. (2015) found that market intermediaries are willing to pay a premium of $\$ 0.13 / \mathrm{lb}$ for an improvement in shelf life from less than to greater than 1 week. Apple growers were also willing to pay a premium of $\$ 0.40 / \mathrm{lb}$ to improve fruit flavor from weak/mild to full/intense. We defined

\footnotetext{
1 The conditional logit model was also estimated for all the crops. We conducted log-likelihood ratio tests comparing the mixed logit model (alternative hypothesis) with the conditional logit model (null hypothesis). All $p$-values for the log-likelihood ratio tests are $<0.01 \%$, indicating the mixed logit model had better goodness of fit for our data than the conditional logit model.
} 
Table 4. Summary Statistics for Respondents' Background and Operations

\begin{tabular}{|c|c|c|c|c|c|c|}
\hline \multirow[b]{2}{*}{ Variable } & \multirow[b]{2}{*}{ Variable Explanation } & \multicolumn{5}{|c|}{ Mean (Standard Deviation) } \\
\hline & & Apple & Peach & Strawberry & Sweet Cherry & Tart Cherry \\
\hline Age & Respondent's age (years) & $59.06(12.24)$ & $55.12(13.19)$ & $57.21(12.71)$ & $57.04(13.56)$ & $59.34(13.07)$ \\
\hline Gender & 1 if male; 0 of female & $0.93(0.26)$ & $0.96(0.20)$ & $0.92(0.28)$ & $0.93(0.26)$ & $0.94(0.25)$ \\
\hline Race & 1 if Caucasian; 0 otherwise & $0.88(0.32)$ & $0.86(0.35)$ & $0.88(0.32)$ & $0.88(0.33)$ & $0.90(0.30)$ \\
\hline \multirow[t]{9}{*}{ Education } & $\begin{array}{l}\text { Respondent's highest level of } \\
\text { formal education: }\end{array}$ & $4.71(2.09)$ & $4.50(2.22)$ & $4.54(2.12)$ & $5.00(1.99)$ & $5.03(2.04)$ \\
\hline & 1. Some high school or less & & & & & \\
\hline & $\begin{array}{l}\text { 2. High school diploma or } \\
\text { equivalent }\end{array}$ & & & & & \\
\hline & 3. Some college, but no degree & & & & & \\
\hline & $\begin{array}{l}\text { 4. Vocational or Extension } \\
\text { certificate }\end{array}$ & & & & & \\
\hline & 5. Two-year college degree & & & & & \\
\hline & 6. Four-year college degree & & & & & \\
\hline & 7. Some graduate school & & & & & \\
\hline & 8. Graduate degree & & & & & \\
\hline
\end{tabular}




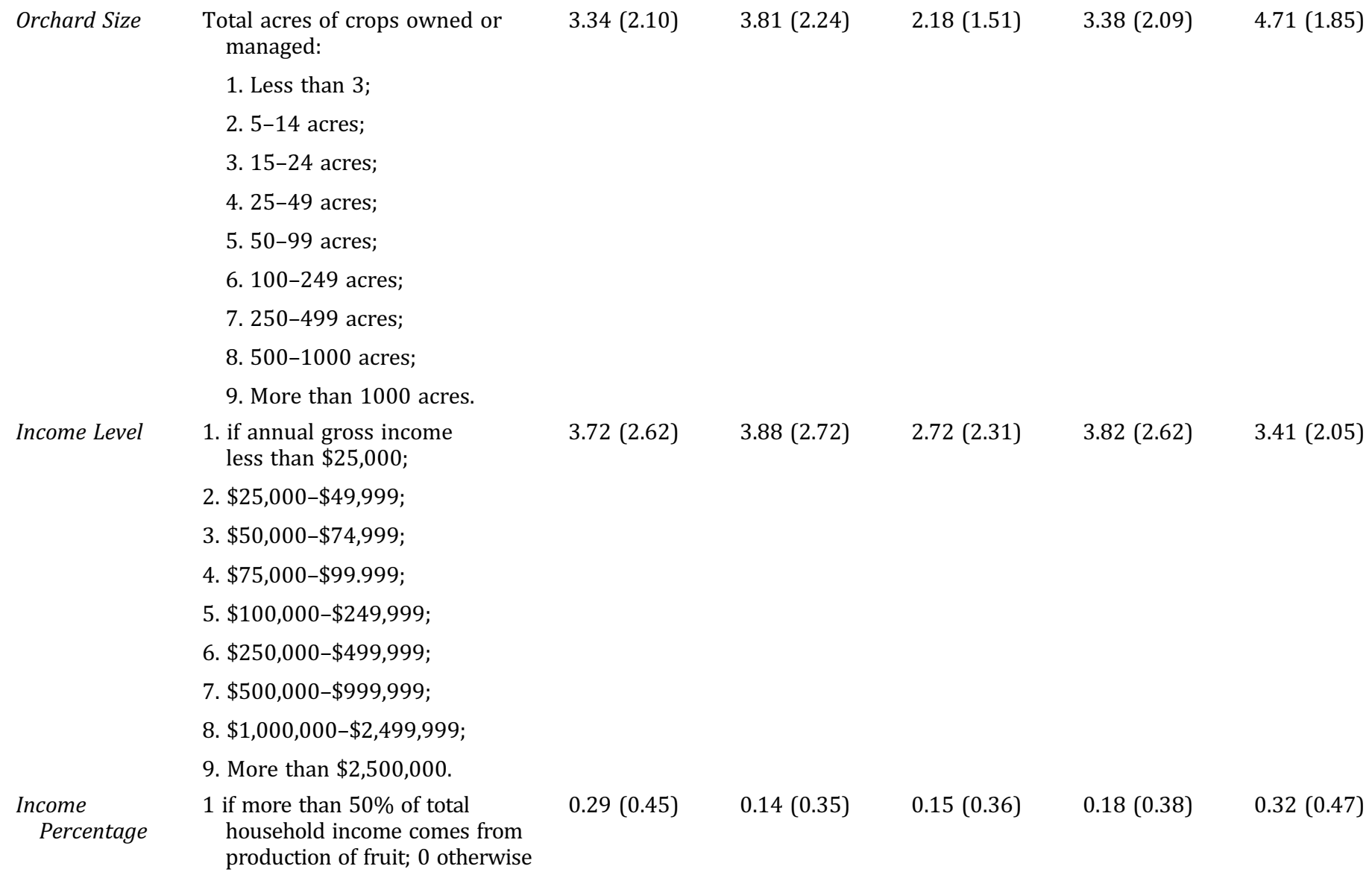

\section{2. $\$ 25,000-\$ 49,999$;}

3. $\$ 50,000-\$ 74,999$;

4. $\$ 75,000-\$ 99.999$;

5. \$100,000-\$249,999;

6. $\$ 250,000-\$ 499,999$;

7. $\$ 500,000-\$ 999,999$;

8. $\$ 1,000,000-\$ 2,499,999$;

9. More than $\$ 2,500,000$.

\section{Income}

1 if more than $50 \%$ of total

$0.29(0.45)$

$0.14(0.35)$

$0.15(0.36)$

$0.18(0.38)$

$0.32(0.47)$ production of fruit; 0 otherwise 
Table 4. Continued

\begin{tabular}{|c|c|c|c|c|c|c|}
\hline \multirow[b]{2}{*}{ Variable } & \multirow[b]{2}{*}{ Variable Explanation } & \multicolumn{5}{|c|}{ Mean (Standard Deviation) } \\
\hline & & Apple & Peach & Strawberry & Sweet Cherry & Tart Cherry \\
\hline $\begin{array}{l}\text { Farm } \\
\quad \text { Operation }\end{array}$ & $\begin{array}{l}1 \text { if family or individual operation } \\
\text { (excluding partnerships and } \\
\text { corporations); } 0 \text { otherwise }\end{array}$ & $0.54(0.50)$ & $0.54(0.50)$ & $0.64(0.48)$ & $0.51(0.50)$ & $0.61(0.49)$ \\
\hline $\begin{array}{l}\text { Years of } \\
\quad \text { Production }\end{array}$ & $\begin{array}{l}\text { Years respondent involved in } \\
\text { production of fruit as a farm } \\
\text { owner, manager, or primary } \\
\text { decision maker }\end{array}$ & $26.38(13.44)$ & $26.24(14.24)$ & $20.96(14.67)$ & $22.37(13.51)$ & $30.90(12.83)$ \\
\hline Interest & $\begin{array}{l}1 \text { if interested in producing fruit } \\
\text { with new or novel fruit } \\
\text { attributes; } 0 \text { otherwise }\end{array}$ & $0.39(0.49)$ & $0.36(0.48)$ & $0.35(0.48)$ & $0.43(0.50)$ & $0.46(0.50)$ \\
\hline Other Function & $\begin{array}{l}1 \text { if performed other functions } \\
\text { such as packing, shipping, or } \\
\text { processing in addition to } \\
\text { production; } 0 \text { otherwise }\end{array}$ & $0.29(0.45)$ & $0.41(0.49)$ & $0.29(0.46)$ & $0.20(0.40)$ & $0.18(0.39)$ \\
\hline $\begin{array}{l}\text { Number of } \\
\quad \text { Respondents }\end{array}$ & & 321 & 124 & 86 & 215 & 99 \\
\hline
\end{tabular}


Table 5. Mixed Logit Model Estimation Results

\begin{tabular}{|c|c|c|c|c|c|}
\hline \multirow[b]{2}{*}{ Parameter } & \multicolumn{5}{|c|}{ Estimate (Standard Error) } \\
\hline & Apple & Peach & Strawberry & Sweet Cherry & Tart Cherry \\
\hline Cost & $-2.61^{* * *}(0.40)$ & $-10.00^{* * *}(0.89)$ & $-0.92^{* * *}(0.16)$ & $-3.78^{* * *}(0.36)$ & $-3.14^{* * *}(0.56)$ \\
\hline External Color & - & $2.00^{* * *}(0.24)$ & $0.66^{* * *}(0.11)$ & $1.61^{* * *}(0.33)$ & $1.35^{* * *}(0.19)$ \\
\hline Size & $0.41^{* * *}(0.07)$ & $1.49^{* * *}(0.23)$ & $0.26^{* * *}(0.08)$ & $3.00^{* * *}(0.41)$ & $0.36^{* *}(0.12)$ \\
\hline Free of defects & $0.15^{* *}(0.07)$ & $1.93^{* * *}(0.27)$ & - & - & $0.67^{* * *}(0.16)$ \\
\hline Firmness & $0.35^{* * *}(0.07)$ & $0.76^{* * *}(0.18)$ & $0.69^{* * *}(0.14)$ & $2.09^{* * *}(0.16)$ & $1.52^{* * *}(0.23)$ \\
\hline Flavor & $1.04^{* * *}(0.11)$ & $2.13^{* * *}(0.24)$ & $1.36^{* * *}(0.19)$ & $2.46^{* * *}(0.27)$ & - \\
\hline Sweetness & - & $1.53^{* * *}(0.23)$ & - & $1.51^{* * *}(0.27)$ & - \\
\hline Crispness & $0.87^{* * *}(0.09)$ & - & - & - & - \\
\hline Internal color & - & - & $0.51^{* * *}(0.08)$ & - & - \\
\hline Shelf life & $1.12^{* * *}(0.11)$ & - & $0.46^{* * *}(0.13)$ & $2.05^{* * *}(0.29)$ & - \\
\hline \multicolumn{6}{|l|}{ Socio-demographics } \\
\hline Acre $^{*}$ Cost & $0.04 *(0.02)$ & $-1.08(0.77)$ & $-0.39^{* *}(0.21)$ & $-0.33^{* * *}(0.13)$ & $-1.16^{* *}(0.50)$ \\
\hline Acre*Free of defects & $0.15^{*}(0.07)$ & $0.38 *(0.22)$ & - & - & $0.13(0.15)$ \\
\hline Acre ${ }^{*}$ Firmness & $0.13^{*}(0.07)$ & $0.17(0.18)$ & $0.02(0.13)$ & $0.48^{* * *}(0.15)$ & $0.30 *(0.16)$ \\
\hline Acre*Sweetness & - & $0.46^{* *}(0.20)$ & - & $-0.27(0.17)$ & - \\
\hline Income $e^{*}$ Cost & $-0.06^{* * *}(0.02)$ & $-0.56(0.67)$ & $0.27(0.20)$ & $-0.21^{*}(0.13)$ & $0.51(0.49)$ \\
\hline Income ${ }^{*}$ Size & $0.11(0.07)$ & $0.60^{* * *}(0.22)$ & $0.00(0.95)$ & $1.18^{* * *}(0.22)$ & $0.06(0.11)$ \\
\hline Income*Flavor & $-0.29^{* * *}(0.09)$ & $-0.57^{* * *}(0.21)$ & $-0.34^{* *}(0.15)$ & $-0.40^{* * *}(0.16)$ & - \\
\hline Education ${ }^{*}$ Cost & $0.03^{* * *}(0.01)$ & $0.76^{* *}(0.32)$ & $0.13(0.11)$ & $0.07(0.08)$ & $0.08(0.32)$ \\
\hline Education*Shelf life & $-0.10(0.08)$ & - & $-0.04(0.12)$ & $-0.14(0.16)$ & - \\
\hline
\end{tabular}

A single asterisk $\left({ }^{*}\right)$, double asterisks $\left({ }^{* *}\right)$, and triple asterisks $\left({ }^{* * *}\right)$ denote significance at the $\alpha=0.1,0.05$, and 0.01 levels, respectively. 
Table 6. Willingness-to-pay Estimates for Rosaceous Fruit Attributes

\begin{tabular}{|c|c|c|c|c|c|}
\hline \multirow[b]{2}{*}{ Attribute } & \multicolumn{5}{|c|}{ Willingness-to-Pay (\$/lb) [95\% Confidence Interval] } \\
\hline & Apple & Peach & Strawberry & Sweet Cherry & Tart Cherry \\
\hline External color & - & $0.20[0.15,0.25]$ & $0.72[0.48,0.95]$ & $0.43[0.26,0.59]$ & $0.44[0.31,0.55]$ \\
\hline Size & $0.16[0.10,0.21]$ & $0.15[0.10,0.19]$ & $0.28[0.11,0.45]$ & $0.80[0.58,1.01]$ & $0.12[0.04,0.19]$ \\
\hline Free of Defect & $0.06[0.00,0.11]$ & $0.19[0.14,0.25]$ & - & - & $0.21[0.11,0.32]$ \\
\hline Firmness & $0.13[0.08,0.18]$ & $0.08[0.04,0.11]$ & $0.76[0.45,1.06]$ & $0.55[0.47,0.64]$ & $0.48[0.34,0.63]$ \\
\hline Flavor & $0.40[0.24,0.48]$ & $0.21[0.17,0.26]$ & $1.48[1.07,1.90]$ & $0.65[0.51,0.79]$ & - \\
\hline Sweetness & - & $0.15[0.11,0.20]$ & - & $0.40[0.26,0.54]$ & - \\
\hline Crispness & $0.33[0.26,0.40]$ & - & - & - & - \\
\hline Internal Color & - & - & $0.56[0.38,0.74]$ & - & - \\
\hline Shelf life & $0.43[0.35,0.51]$ & - & $0.50[0.22,0.78]$ & $0.54[0.39,0.69]$ & - \\
\hline
\end{tabular}


flavor as the combination of sweetness and sweet/tart balance and aroma, so this result aligns with findings by others that consumers prefer higher sweetness, acidity, and juice content (Jesionkowska et al. 2006, Kajikawa 1998).

In this study, growers were willing to pay a premium price of $\$ 0.33 / \mathrm{lb}$ for a crisp apple compared to a noncrisp apple, which coincides with findings by Manalo (1990) that consumers in the northeastern United States value apple crispness more than size and color. Finally, this study revealed apple growers would pay a premium of $\$ 0.16 / \mathrm{lb}$ to improve size from smaller than to larger than 2.9 inches; $\$ 0.13 / \mathrm{lb}$ for firmer apples, from less than to greater than 14 $\mathrm{lbs}$; and $\$ 0.06 / \mathrm{lb}$ to improve external appearance from greater than to less than 3\% apples with defects per lot/lb. Our results for growers are different than previous findings of McCluskey et al. (2013) on consumer WTP for apple attributes, indicating that consumers are willing to pay a higher premium for firmness compared to sweetness. Specifically for the apple cultivar Red Delicious, consumer WTP for firmness could be as high as $\$ 1.16 / \mathrm{lb}$. In a different study of consumers, Jesionkowska et al. (2006) found firmness to be the third most important attribute after flavor and juiciness.

Peach growers were willing to pay a premium of $\$ 0.21 / \mathrm{lb}$ to improve flavor from mild to intense and $\$ 0.20 / \mathrm{lb}$ to improve external color from lack of skin blush to cream/yellow background with a red blush. Flavor commanded the highest premium for fresh market peach growers, whether based in California, which accounts for around $51 \%$ of total U.S. supply (National Agricultural Statistics Service 2012), or in eastern states. An earlier study (Park and Florkowski, 2003) also found taste to be the principal explanation for growers' acceptance of a new cultivar. In this study we found peach growers were willing to pay $\$ 0.19 / \mathrm{lb}$ to improve external appearance from fair ( $<70 \%$ packout) to good ( $>85 \%$ packout), $\$ 0.15 / \mathrm{lb}$ to increase size from 2.25-2.5 inches diameter to $2.75-3$ inches diameter, and $\$ 0.15 / \mathrm{lb}$ to enhance sweetness from low $\left(<11^{\circ}\right.$ Brix) to high $\left(>11{ }^{\circ}\right.$ Brix). Our results are consistent with previous findings, that freedom from defects, maturity, and size correlate positively with fresh peach prices (Jordan et al. 1986, Parker et al. 1991). However, for market intermediaries, Gallardo et al. (2015) found peach size to e more important than external color and flavor, perhaps because peach size is a major criterion to set grades and a key factor in ease of packing and shipping for marketing intermediaries. Finally, compared to the other attributes considered for peaches in our study, firmness generated a relatively smaller WTP value of $\$ 0.08 / \mathrm{lb}$.

Strawberry growers were willing to pay the highest premium $(\$ 1.48 / \mathrm{lb})$ to improve fruit flavor from weak/mild to full/intense, consistent with preferences of market intermediaries (Gallardo et al. 2015) and consumers (Colquhoun et al. 2012). Growers were willing to pay $\$ 0.76 / \mathrm{lb}$ more to improve fruit firmness from soft to firm. Previous studies have shown mixed results in terms of consumer preferences for strawberry firmness. While Safley et al. (1999) found consumers identify firmness as one of the top three attributes for strawberry, Ford (1996) concluded that firmness is the least 
important for consumers compared to flavor, appearance, color, shape, juiciness, and sweetness. In our study, the premiums to improve fruit external color and internal color from too light or too dark to ideal red are $\$ 0.72 / \mathrm{lb}$ and $\$ 0.56 / \mathrm{lb}$, respectively. Lastly, growers were willing to pay $\$ 0.50 / \mathrm{lb}$ to improve shelf life from 4 days after harvest to 9 days after harvest and $\$ 0.28 / \mathrm{lb}$ to increase the fruit size from less than $25 \mathrm{~g} /$ fruit to greater than $25 \mathrm{~g} /$ fruit. Different from these findings for growers, market intermediaries regard size as a more important attribute than color and shelf life, perhaps because firmness and size are both key factors in U.S. standards for grades of strawberries. This commands markets prices and thus affects intermediaries' profitability (Gallardo et al. 2015).

Sweet cherry growers in this study indicated larger fruit size was their most desired attribute, with a WTP value of $\$ 0.80 / \mathrm{lb}$ to increase size from 11 row (24.2-mm diameter) or smaller to 10 row (26.6-mm diameter) or larger. Earlier studies on consumer preference for sweet cherry attributes have shown mixed results. Turner et al. (2005) indicated sweetness and not size to be the most important criterion for consumers choosing the sweet cherry they liked. Zheng et al. (2016) found sweet cherry consumers were willing to pay the highest premium for sweetness and the lowest premium for size. In contrast, here we found growers were willing to pay the highest premium for size while the premium for sweetness was ranked the lowest among the attributes included in our study. However, Dever et al. (1996) reported consumers preferred larger fruit, and Kappel et al. (1996) suggested an optimal size of $29-30 \mathrm{~mm}$ in diameter. The improvement in flavor from weak/mild to full/intense generated the second highest WTP value of $\$ 0.65 / \mathrm{lb}$, and participants in our study indicated shelf life to be the third most important attribute, with the WTP of $\$ 0.54 / \mathrm{lb}$ to improve shelf life at retail from less than a week to more than a week. This aligns with results from an earlier market intermediary study (Gallardo et al. 2015) that shelf life, SSC level and flavor are the most important attributes for sweet cherry, and size was perceived to be less important. Sweet cherry has a short marketing window, and quality deteriorates rapidly due to softening, surface pitting, stem browning, and loss of acidity (Serrano et al. 2005). This study found a WTP premium of $\$ 0.55 / \mathrm{lb}$ by growers to improve fruit firmness from soft to firm, and a premium of $\$ 0.43 / \mathrm{lb}$ to improve external color from light red to dark red. Growers are willing to pay $\$ 0.40 / \mathrm{lb}$ to improve sweetness from $<18{ }^{\circ}$ Brix to $>18{ }^{\circ}$ Brix. Other studies noted that consumer acceptance of Brooks and Bing cherries was mainly dependent on fruit SSC level and visual skin color (Crisosto et al. 2003), which may in turn affect growers' preferences for certain sweet cherry cultivars. Similarly, Kappel et al. (1996) indicated the minimum sweetness level for sweet cherry should be $17-19^{\circ} \mathrm{Brix}$.

For tart cherry, four attributes (firmness, external color, uniform size, uniform appearance) were included in the choice experiment. Tart cherry fruits are generally processed in a range of canned, frozen, or dried products. Firmness (improving from soft to firm) and external color (improving from poor red 
color to characteristic bright red color) had the highest WTP premiums $(\$ 0.48$ / lb. and $\$ 0.44 / \mathrm{lb}$, respectively). Growers indicated a WTP premium of $\$ 0.21 / \mathrm{lb}$ to improve from $>4 \%$ of fruits with defects per lot to $<4 \%$ of fruits with defects per lot, $\$ 0.12 / \mathrm{lb}$ to improve external appearance from nonuniform to uniform. These values are consistent with the processing standards, as noted by Siddiq et al. (2011), because firmness and external color are crucial for the stability and attractiveness of final products, especially for tart cherry juice/ concentration. Iezzoni (2010) also concluded these traits, along with size uniformity and ease of pit removal, were important for frozen products.

We also included the interactions between fruit attributes and growers' sociodemographic characteristics to allow for trait attribute valuation to vary across sociodemographic groups. The interactions were standardized with a mean of 0 and a standard deviation of 1 . The sociodemographic characteristics we included were total acres owned or managed, annual income, and educational level. We found that the three demographic characteristics affected growers' preference for fruit attributes in similar patterns across crops. The coefficients for the interactions between total acreage and cost was significant and negative for strawberry, sweet cherry, and tart cherry, indicating that larger-scale growers tend to be more sensitive to costs compared to smaller-scale growers. At the same time, acreage also affects grower preferences for certain fruit attributes. For example, larger-scale apple and sweet cherry growers were willing to pay more for improvement in firmness than smaller-scale growers, while larger-scale peach growers had a stronger preference for external appearance and sweetness improvement than smaller-scale ones. The coefficients of the interactions between income and cost were significant and negative for apple and sweet cherry growers, indicating apple and sweet cherry growers with higher incomes were less sensitive to the increased costs of cultivars with improved attributes. Peach and sweet cherry growers with higher income levels were willing to pay more for improved firmness compared to those with lower income levels. Interestingly, the coefficients of the interactions between income and flavor were significant and negative for all crops, indicating that wealthier growers were willing to pay less for flavor enhancement compared to growers with lower income levels. Lastly, the coefficients of the interactions between education level and cost were positive and significant for apple and peach growers, indicating more educated growers were less sensitive to cost increases for apple and peach cultivars with improved attributes.

\section{Conclusions}

We elicited growers' preferences for fruit quality attributes using a nationally representative sample of producers of five rosaceous crops. Our empirical model was developed using a random utility theory framework that assumes growers derive utility when they realize augmented profits due to their 
investment choices. We used mixed logit models for parameter estimation and calculation of WTP premiums.

Many factors could influence growers' decisions to adopt and grow improved fruit cultivars. Even though growers' demand for improved fruit cultivars are influenced by consumers' demands for such cultivars, the "derived" producer demand and the "primary" consumer demand might not perfectly match. Our results reinforce conclusions presented in previous investigations of fruit quality attribute valuations among general supply chain stakeholders, highlighting differences and similarities among the crops studied.

Additionally, our results are applicable to genetic manipulation of target traits in rosaceous crop-breeding programs, and we introduce a quantitative economic measure, the willingness to pay a premium - WTP - that can provide useful direction to those breeding programs and subsequent investigations. Some specific results merit attention. When the economic product is intended for the fresh market, fruit flavor was clearly among the most important fruit attributes for four of those crops (apple, peach, strawberry, and sweet cherry). For tart cherry, typically destined for the processed market, fruit firmness and color ranked as the two most important attributes. In addition to fruit flavor, apple growers were willing to pay higher price premiums for improved shelf life and crispness; peach growers for flavor, external color enhancement, and appearance; and strawberry growers for improved firmness, and color. Sweet cherry growers favored increased fruit size over fruit flavor, and also valued increased shelf life. Tart cherry growers most valued enhanced external color and firmness for processing purposes, a result consistent with the notion that tart cherry growers consider the processer, rather than the consumer, as their target market.

Growers' priorities in this study contrast somewhat with breeders' priorities in a previous study by Gallardo et al. (2012), which showed apple and strawberry breeders placed highest priority on texture, followed by flavor, while peach breeders set a high priority on appearance, followed by texture and flavor. The specific economic valuation placed by growers on individual attributes can now provide breeding programs more specific information to evaluate the fruit quality trait, and the targeted levels for that trait, within their programs. Consumers and market intermediary WTP available in other studies (e.g., Gallardo et al. 2015, Lado et al. 2010, McCluskey et al. 2013) can be combined with these new insights, thereby enhancing the effectiveness and creativity of those programs. Ultimately all stakeholders along the supply chain benefit from the superior new cultivars that can contribute not only to industry profitability and sustainability, but to the enjoyment and well-being of consumers of rosaceous crops.

\section{Reference Cited}

Colquhoun, T.A., L.A. Levin, H.R. Moskowitz, V.M. Whitaker, D.G. Clark, and K.M. Folta. 2012. "Framing the Perfect Strawberry: An Exercise in Consumer-Assisted Selection of Fruit Crops." Journal of Berry Research 2(1): 45-61. 
Crisosto, C.H., G.M. Crisosto, and P. Metheney. 2003. "Consumer Acceptance of 'Brooks' and 'Bing' Cherries is Mainly Dependent on Fruit SSC and Visual Skin Color." Postharvest Biology and Technology 28(1): 159-167.

Dever, M.C., R.A. MacDonald, M.A. Cliff, and W.D. Lane. 1996. "Sensory Evaluation of Sweet Cherry Cultivars." HortScience 31(1): 150-153.

Dillman, D., J.D. Smyth, and L.M. Christian. 2009. Mail, Internet, and Mixed Mode Surveys: The Tailored Design Method. New York: John Wiley.

Ding, M., and Y. Lu. 2004. "Inhibition of AP-1 and Neoplastic Transformation by Fresh Apple Peel Extract.” The Journal of Biological Chemistry, 279(11): 10670-10676.

Ford, A., K. Hansen, M. Herrington, J. Moisander, S. Nottingham, S. Prytz, and M. Zorin. 1996. "Subjective and Objective Determination of Strawberry Quality." Acta Horticulturae, 439: 319-323.

Gallardo, R.K., D. Nguyen, V. McCracken, C. Yue, J. Luby, and J. McFerson. 2012. "An Investigation of Trait Prioritization in Rosaceous Fruit Breeding Programs." HortScience 47(6): 771-776.

Gallardo, R.K., H. Li, V. McCracken, C. Yue, J. Luby, and J. McFerson. 2015. "Market Intermediaries' Willingness to Pay for Apple, Peach, Cherry, and Strawberry Quality Traits." Agribusiness 31(2): 259-280.

Greene, W.H., and D.A. Hensher. 2010. Modeling Ordered Choices: A Primer. Cambridge: Cambridge University Press.

Iezzoni, A. 2010. "Jewels in the Genome." RosBREED Newsletter 1(1): 9.

Jesionkowska, K., D. Konopacka, and W. Ploscharski. 2006. "The Quality of Apples Preferences Among Consumers from Skierniewice, Poland." Journal of Fruit and Ornamental Plant Research 14: 173-182.

Jordan, J.L., R.L. Shewfelt, and S.E. Prussia. 1986. "The Value of Peach Quality Characteristics in the Postharvest System." In IX Symposium on Horticultural Economics 203: 175-182.

Kajikawa, C. 1998. "Quality Level and Price in Japanese Apple Market." Agribusiness 14(3): 227-234.

Kappel, F., B. Fisher-Fleming, and E. Hogue. 1996. "Fruit Characteristics and Sensory Traits of an Ideal Sweet Cherry." HortScience 31(3): 443-46.

Lado, J., E. Vicente, A. Manzzioini, and G. Ares. 2010. "Application of a Check-All-that-Apply Question for the Evaluation of Strawberry Cultivars from a Breeding Program." Journal of the Science of Food and Agriculture 90(13): 2268-2275.

Louviere, J.J., D.A. Hensher, and J.D. Swait. 2000. Stated Choice Methods: Analysis and Applications. Cambridge: Cambridge University Press.

Lusk, J.L., M. Jamal, L. Kurlander, M. Roucan, and L. Taulman. 2005. "A Meta-Analysis of Genetically Modified Food Valuation Studies." Journal of Agricultural and Resource Economics 30(1): 28-44.

Lusk, J. and D. Hudson. 2004. "Willingness-to-Pay Estimates and Their Relevance to Agribusiness Decision Making." Review of Agricultural Economics 26(2): 152-169.

Manalo, A.B. 1990. "Assessing the Importance of Apple Traits: An Agricultural Application of Conjoint Analysis." Northeastern Journal of Agricultural and Resource Economics 19(2): 118-124.

McCluskey, J.J., B.P. Horn, C.A. Durham, R.C. Mittelhammer, and Y. Hu. 2013. "Valuation of Internal Quality Characteristics across Apple Cultivars." Agribusiness 29(2): 228-241.

Ouma, E., A. Abdulai, and A. Drucker. 2007. "Measuring Heterogeneous Preferences for Cattle Traits among Cattle-Keeping Households in East Africa." American Journal of Agricultural Economics. 89(4): 1005-1019.

Park, T.A. and W.J. Florkowski. 2003. "Selection of Peach Varieties and the Role of Quality Traits." Journal of Agricultural and Resource Economics 28(1): 138-151.

Parker, D.D., D. Zilberman, and K.S. Moulton. 1991. "How Quality Relates to Price in California Fresh Peaches." California Agriculture 45(2): 14-16. 
Predieri, S., P. Ragazzini, and R. Rondelli. 2006. Sensory Evaluation and Peach Fruit Quality. Acta Horticulturae 713: 429-434.

Ravaglia, G., S. Sansavini, M. Ventura, and D. Tabanelli. 1996. "Indici di Maturazione e Miglioramiento Qualitative delle Pesche." Fruitcoltora 3; 61-66.

Safley, C.D., M.K. Wohlgenant, and R. Edens Suter. 1999. Factors Affecting Consumers Purchases Direct Market Strawberries. Department of Agricultural and Resource Economics, ARE Report 22. North Carolina State University.

SAS Institute Inc. 2009. JMP ${ }^{\circledR} 8$ User Guide, Second Edition. Cary, NC: SAS Institute Inc.

Serrano, M., D. Martínez-Romero, S. Castillo, F. Guillén, and D. Valero. 2005. "The Use of Natural Antifungal Compounds Improves the Beneficial Effect of MAP in Sweet Cherry Storage." Innovative Food Science and Emerging Technologies 6(1): 115-23.

Train, K. 2009. Discrete Choice Methods with Simulation, 2nd edition. Cambridge: Cambridge University Press.

Tonsor, G.T., N. Olynk, and C. Wolf. 2009. "Consumer Preference for Animal Welfare Attributes: The Case of Gestation Crates." Journal of Agricultural and Applied Economics 41(3): 713-730.

Siddiq, M., A. Iezzoni, A. Khan, P. Breen, A.M. Sebolt, K.D. Dolan, and R. Ravi. 2011. "Characterization of New Tart Cherry (Prunus cerasus L.): Selections Based on Fruit Quality, Total Anthocyanins, and Antioxidant Capacity." International Journal of Food Properties, 14(2), 471-480.

Turner, J., C. Seavert, A. Colonna, and L.E. Long. 2005. “Consumer Sensory Evaluation of Sweet Cherry Cultivars in Oregon, USA." In V International Cherry Symposium 795: 781-786.

Yue, C. and C. Tong. 2011. "Consumer Preferences and Willingness to Pay for Existing and New Apple Varieties: Evidence from Apple Tasting Choice Experiments." HortTechnology 21(3): 376-83.

Yue, C., R.K. Gallardo, J. Luby, A. Rihn, J.R. McFerson, V. McCracken, D. Bedford, S. Brown, K. Evans, C. Weebadde, and A. Sebolt. 2013. "An Investigation of U.S. Apple Producers' Trait Prioritization-Evidence from Audience Surveys." HortScience 48(11): 1378-1384.

Yue, C., R.K. Gallardo, V.A. McCracken, J. Luby, J.R. McFerson, L. Liu, and A. Iezzoni. 2012. "Technical and Socio-Economic Challenges to Setting and Implementing Priorities in North American Rosaceous Fruit Breeding Programs." HortScience 47(9): 1320-1327.

Zapata, S.D. and C.E. Carpio. 2014. "The Theoretical Structure of Producer Willingness to Pay Estimates." Agricultural Economics 45(5): 613-623.

Zheng, X., C. Yue, K. Gallardo, V. McCracken, J. Luby, and J. McFerson. 2016. "What attributes are consumers looking for in sweet cherries? Evidence from choice experiments" Agricultural and Resource Economics Review 45(1): 124-142. 